\title{
IMIGRANCI W HISZPANII W DOBIE KRYZYSU. REAKCJE HISZPAŃSKIEJ OPINII PUBLICZNEJ I PRASY W OKRESIE 2008-20111
}

\author{
IMMIGRATION IN SPAIN IN TIMES OF CRISIS. \\ SPANISH PUBLIC OPINION AND PRESS \\ REACTIONS IN THE PERIOD FROM 2008 TO 2011
}

\begin{abstract}
In recent decades immigrants considerably influence the social and cultural landscape of Spain. The immigration brings a new dimension of multiculturalism and enriches the hybrid (ethnic, regional, linguistic) Spanish identity. All immigrant communities are factors of cultural change in different levels of social life. Their impact on the receiving society can be both measured through the "hard" statistical data and described from the subjective perspective focusing on the social representations, expectations, fears, lifestyle and mentality changes, cultural closeness and remoteness, etc. Over the last years the global crisis has been a idée fixe of the socio-economic (but also cultural) discourse in many parts of the world. Spain was placed among countries most affected by the recession. Its economic downturn and social impasse led to internal political crisis (the accelerated general elections in 2011) and to the protest movement Indignados fighting for better conditions for life. Immigrants have become one the most relevant participants of the social changes in times of recession and conflicts. The intent of this article is to present the situation of the immigrant community in Spain in the period from 2008 to 2011, in reference to statistical reports, public opinion surveys and selected comments of Spanish press.
\end{abstract}

Key words: Spain; immigration; crisis; public opinion; Spanish press

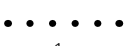

1 Pracę nad tekstem zakończyłam w maju 2012 roku. Wszystkie dane i komentarze zawarte w artykule odnoszą się do sytuacji poprzedzającej ten moment. Cytaty z języka hiszpańskiego podaję w przekładzie własnym.

This is an Open Access article distributed under the terms of the Creative Commons Attribution 3.0 PL License (creativecommons.org/licenses/by/3.0/pl/), which permits redistribution, commercial and non-commercial, provided that the article is properly cited. (C) The Author(s) 2014.

Publisher: Institute of Slavic Studies PAS [Wydawca: Instytut Slawistyki PAN] 
Imigranci są od kilku dekad bardzo istotnym elementem hiszpańskiego społeczeństwa. Ich obecność w Hiszpanii to stosunkowo nowe oblicze wielokulturowości, wspótistniejące (nie zawsze zgodnie) z innymi składnikami złożonej hiszpańskiej tożsamości: etnicznej czy regionalnej. Społeczności imigranckie są często nośnikiem zmiany kulturowej na różnych poziomach życia społecznego. Bywają motorem przemian zarówno w sensie obiektywnym, co pokazują "twarde" dane (wpływ na rynek pracy i strukturę zatrudnienia, system edukacji, czy kierunek polityki społecznej), jak i w wymiarze bardziej subiektywnym, dotyczącym społecznych wyobrażeń, oczekiwań, niepokojów (przemiany stylu życia, mentalności, dynamika tolerancji vs. zamknięcia kulturowego, poczucie nowych zagrożeń w społeczeństwie przyjmującym etc.).

W ostatnich latach tematem przewodnim debaty społeczno-ekonomicznej, ale także kulturowej, stał się postępujący kryzys dotykający zachodnie społeczeństwa. Hiszpania to jeden z tych krajów, w których ten impas przyjął szczególnie wyrazistą formę. Świadczyły o tym m.in. zawirowania na wewnętrznej scenie politycznej (przyspieszone wybory parlamentarne w 2011 r.), czy powstające ruchy społeczne walczące o poprawę warunków życia: Indignados. Imigranci stali się ważnymi uczestnikami wydarzeń i przemian społecznych w dobie recesji i konfliktów. Celem artykułu jest przedstawienie sytuacji społeczności imigranckich w Hiszpanii w latach 2008-2011, w odwołaniu do raportów statystycznych i sondaży opinii publicznej w Hiszpanii oraz wybranych komentarzy hiszpańskiej prasy.

Stowa kluczowe: Hiszpania; imigranci; kryzys; opinia publiczna; prasa

$\mathrm{H}$ iszpania jest niewątpliwie jednym z najbardziej fascynujących krajów Europy. Zaciekawia nie tylko pod względem turystycznym, podróżniczym, estetycznym, kulturowym, ale także interesuje - zarówno miłośników hiszpańskich klimatów, jak i profesjonalnych badaczy - z powodu swojej wyjątkowej, mozaikowej struktury. Zróżnicowanie Królestwa Hiszpanii przejawia się w różnych wymiarach: geograficznym, krajobrazowym, kulturowo-etnicznym, językowym. Na te podziały nakładają się różnice o charakterze polityczno-społecznym czy ekonomicznym, zauważalne poprzez rozbicie kraju na poszczególne wspólnoty autonomiczne. Te widoczne współcześnie kontrasty regionalne mają swoje źródła w historii i tradycji ziem Półwyspu lberyjskiego, wynikają z krzyżowania się odmiennych wpływów etnicznych i religijnych, z oddziaływania różnych prądów kulturowych czy systemów rządzenia i ideologii.

Imigranci są wspótcześnie bardzo wyrazistym i ważnym elementem hiszpańskiego społeczeństwa. Ich obecność w Hiszpanii należałoby traktować jako nowy wymiar wielokulturowości, czasem współbrzmiący, a czasem pozostający w dysonansie z innymi składnikami hiszpańskich tożsamości. Mówiąc o tożsamości w kontekście mieszkańców Półwyspu Iberyjskiego, trzeba pamiętać o wielu jej odmianach, stanowiących odzwierciedlenie różnic regionalnych i lokalnych. Społeczności imigranckie są zawsze nośnikiem zmiany kulturowej na wielu poziomach życia społecznego. Także w Hiszpanii ich obecność kształtuje długofalowe przemiany społeczeństwa. Ale imigranci bywają nie tylko motorem zmian; sami również są doświadczani przez zmieniającą się wokół nich rzeczywistość: zależą od nastrojów społecznych (wzrost tolerancji i zrozumienia dla idei międzykulturowości lub przeciwnie: narastające tendencje ksenofobiczne i neorasistowskie); na ich warunki życiowe oddziałują prawo i polityka imigracyjna w państwie przyjmującym; wreszcie - w dotkliwy sposób odczuwają zmiany gospodarcze, czego doskonałym przykładem może być kryzys ekonomiczny w ostatnich latach. 
Hiszpania, podobnie jak Włochy, była tradycyjnie krajem emigracji, wysyłającym swoich obywateli do innych, mniej lub bardziej odległych zakątków świata. O pierwszych falach wyjazdów Hiszpanów z kraju należałoby mówić w odniesieniu do podbojów Nowego Świata, czyli od końca XV wieku (Miłkowski \& Machcewicz, 1998) 2. Mieszkańcy Hiszpanii zasiedlali nowo podbite terytoria po drugiej stronie Atlantyku, co stało się przedmiotem wielu studiów prowadzonych jeszcze w XIX wieku i kontynuowanych do dzisiaj (González Leandri, 2004; González Martínez, 2004). Nie należy zapominać, że to właśnie potomkowie Hiszpanów osiadłych w południowoamerykańskich koloniach, Kreole, stanęli na czele buntów miejscowej ludności, które w rezultacie doprowadziły do wyswobodzenia tamtej części świata spod wpływów kolonizatorów (Miłkowski \& Machcewicz, 1998, ss. 245-247).

Na przełomie wieków XIX i XX, w okresie tzw. Wielkiej Emigracji, Hiszpanie wyjeżdżali za ocean w poszukiwaniu lepszych warunków życia. Głównymi kierunkami stały się Kuba, Puerto Rico, Argentyna i inne kraje Ameryki Południowej. XIX wiek to także okres emigracji hiszpańskiej do Maroka. Kolejne fale wyjazdów z Hiszpanii przypadają na lata wojny domowej i długi okres dyktatury generała Francisco Franco. Hiszpanie udawali się wówczas zarówno do Ameryki Południowej, jak i do krajów europejskich: Francji (która w czasie wojny domowej dała schronienie republikańskiemu rządowi), Wielkiej Brytanii, Szwajcarii czy Belgii (Miłkowski \& Machcewicz, 1998, ss. 305, 336, 394, 413 i n.). Okres po 1975 roku, czyli kiedy oficjalnie zakończyła się dyktatura, charakteryzował się powrotami hiszpańskich emigrantów do kraju. Równolegle rozpoczął się także inny fenomen: do Hiszpanii zaczęli ściągać cudzoziemcy. Imigracja jest więc dla Hiszpanów zjawiskiem względnie nowym, zauważalnym od lat 80. XX wieku. Masowa migracja na teren krajów basenu Morza Śródziemnego, w tym na terytorium hiszpańskie, była w dużej mierze spowodowana wprowadzeniem restrykcyjnej polityki imigracyjnej w innych krajach Europy Zachodniej, które wcześniej przyjmowały imigrantów (Romaniszyn, 1999, s. 61).

\section{IMIGRANCI W HISZPANII JAKO NOWY WYMIAR WIELOKULTUROWOŚCI}

Jak wskazują dane Eurostat, w 2010 roku w 27 krajach Unii Europejskiej mieszkało łącznie 32,5 mln cudzoziemców, co stanowiło 6,5\% całej „europejskiej” populacji. Większość z tych cudzoziemców (20,2 mln) stanowili obywatele krajów nienależących do UE, natomiast pozostałe 12,3 mln byli to obywatele innych krajów członkowskich Unii (Eurostat, 2011). W Hiszpanii, której populacja wynosi obecnie prawie $46 \mathrm{mln}$, cudzoziemcy stanowili w 2010 roku ponad 12,3\% całej populacji (5 663 500) $)^{3}$. Sytuuje to Królestwo Hiszpanii w czołówce krajów członkowskich UE o największej liczbie imigrantów.

Imigranci osiadają najchętniej w tych rejonach kraju, w których mają więcej możliwości znalezienia pracy oraz tam, gdzie istnieją już sieci migracyjne stworzone przez poprzedników. Obszary o najwyższej liczbie imigrantów to w Hiszpanii przede wszystkim stolica i jej okolice, wybrzeże Morza Śródziemnego oraz hiszpańskie wyspy. Cudzoziemcy z krajów należących do UE (których z tego względu raczej trudno nazywać „,imigrantami”) najczęściej osiadają w rejonie oznaczanym jako Levante ${ }^{4}$, a także w Andaluzji, na Balearach oraz na Wyspach Kanaryjskich. Według danych INE miejscowością o największej liczbie

\footnotetext{
.....
}

2 Nie wliczam w tę kategorię przymusowych wyjazdów Żydów i Morysków, którzy w wyniku prowadzonej w XVI i XVII wieku polityki hiszpańskiej Korony musieli opuścić terytorium dzisiejszej Hiszpanii.

3 Eurostat. Dane Instituto Nacional de Estadística nieco się różnią: 5751487 to liczba wszystkich cudzoziemców w Hiszpanii według Spisu Ludności (rejestru ludności) z 2011, za: http://www.ine.es/jaxi/tabla.do

4 Lewant hiszpański - umowna nazwa wschodniej części hiszpańskiego wybrzeża śródziemnomorskiego. Do Lewantu zalicza się zazwyczaj nadmorskie prowincje Katalonii (Tarragonę, Barcelonę i Gironę), wspólnoty 
cudzoziemców jest San Fulgencio w okolicach Alicante (prawie 76\%) (Manjavacas, 2011). Paradoksalnie, najczęściej używanym językiem jest tam angielski. W Hiszpanii istnieje także charakterystyczny podział narodowościowo-terytorialny. Poszczególne grupy przybyszów koncentrują się w pewnych rejonach krajów. Ekwadorczycy osiedlają się głównie w Madrycie, Murcji a także w Barcelonie. Stolica kraju i stolica Katalonii przyciągają także innych imigrantów z krajów latynoskich. Rumuni osiadają przeważnie w okolicach Madrytu oraz Castellón. Andaluzja jest regionem najchętniej wybieranym przez Marokańczyków (choć wcześniej zasiedlali oni licznie również Madryt i Barcelonę). W rejonie Alicante i Malagi przeważają obywatele Wielkiej Brytanii, natomiast Niemcy najczęściej osiadają na hiszpańskich wyspach (INE, 2012a). Cudzoziemcy mieszkający w Hiszpanii i pochodzący z któregoś z krajów UE stanowią w sumie 2392 491. Najwięcej jest Rumunów (864 278), następnie Brytyjczyków (390 880) i Niemców (195 842). Spośród cudzoziemców spoza UE na pierwszym miejscu plasują się Marokańczycy (769 920), następnie Ekwadorczycy (359 076) i Kolumbijczycy (271 773). W 2011 roku po raz pierwszy nie zanotowano wzrostu całkowitej liczby imigrantów w Hiszpanii, aczkolwiek niektóre z grup powiększyły swój skład: np. Rumuni, Marokańczycy, Pakistańczycy i Chińczycy. Jeżeli chodzi o rozkład regionalny, najbardziej reprezentowaną grupą cudzoziemców w Hiszpanii są obywatele państw członkowskich UE-27 (41,7\%), następnie Ameryki Południowej (24,8\% wszystkich cudzoziemców) (INE, 2012a).

Tabela 1. Imigracja w Hiszpanii - tendencje przemian

\begin{tabular}{|c|c|c|}
\hline Rok & L/osoby zarejestrowane & \% populacji \\
\hline 1981 & 198042 & 0,52 \\
\hline 1991 & 360655 & 0,91 \\
\hline $\mathbf{2 0 0 1}$ & $\mathbf{1} \mathbf{1 0 9} \mathbf{0 6 0}$ & $\mathbf{3 , 3 3}$ \\
\hline $\mathbf{2 0 0 4}$ & $\mathbf{3 0 3 4} \mathbf{3 2 6}$ & $\mathbf{7 , 0 2}$ \\
\hline 2005 & 3730610 & 8,46 \\
\hline 2006 & 4144166 & 9,27 \\
\hline 2007 & 4519554 & 10,0 \\
\hline 2008 & 5220600 & 11,3 \\
\hline 2009 & 5598691 & 12,0 \\
\hline $\mathbf{2 0 1 0}$ & $\mathbf{5 7 4 7} \mathbf{7 3 4}$ & $\mathbf{1 2 , 2}$ \\
\hline $\mathbf{2 0 1 1}$ & $\mathbf{5 7 3 0 6 6 7}$ & $\mathbf{1 2 , 2}(-37.056)$ \\
\hline
\end{tabular}

Opracowanie własne na podstawie danych Instituto Nacional de Estadística, www.ine.es.

Wspólnoty autonomiczne o najwyższym odsetku cudzoziemców w stosunku do rodzimej populacji to Baleary (21,8\%), Wspólnota Autonomiczna Walencji (17,2\%), a także Wspólnota Autonomiczna Madrytu i Murcja (w obydwu cudzoziemcy stanowią 16,4\%). Obszary o najmniejszym odsetku cudzoziemców to Estremadura (3,7\%), Galicja (3,9\%) oraz Księstwo Asturii (4,7\%). W stosunku do danych z 1 stycznia 2010 roku, największy przyrost cudzoziemców w wartościach absolutnych nastąpił w Andaluzji (23 120), Kraju Basków (5182) oraz w Estremadurze (2104). Natomiast wspólnoty autonomiczne, w których najbardziej zmalała liczba imigrantów to: Madryt, Walencja i Katalonia (INE, 2011).

autonomiczne Walencji i Murcji oraz prowincję Almería w Andaluzji, jak również wschodnie rejony Aragonii i Kastylii La Manchy. 
Tabela 2. 10 najliczniejszych grup cudzoziemskich, według narodowości

\begin{tabular}{|l|c|c|c|}
\hline Narodowość & $\mathbf{2 0 0 1}$ & $\mathbf{2 0 1 1}$ & \%* \\
\hline Rumuni & 31641 & 864278 & 15,1 \\
\hline Marokańczycy & 233415 & 769920 & 13,4 \\
\hline Brytyjczycy & 107326 & 390880 & 6,8 \\
\hline Ekwadorczycy & 139022 & 359076 & 6,3 \\
\hline Kolumbijczycy & 87209 & 271773 & 4,3 \\
\hline Boliwijczycy & 6619 & 197895 & 3,5 \\
\hline Niemcy & 99217 & 187847 & 3,4 \\
\hline Włosi & 34689 & 195842 & 3,3 \\
\hline Bułgarzy & 12035 & 172634 & 3,0 \\
\hline Chińczycy & 27574 & 166223 & 2,9 \\
\hline
\end{tabular}

Opracowanie własne na podstawie danych INE ${ }^{6}$.

* Odsetek w stosunku do wszystkich cudzoziemców zarejestrowanych w Hiszpanii

Imigracja w Hiszpanii charakteryzuje się również wyraźnymi podziałami etniczno-płciowymi. Ameryka Łacińska i Południowa to rejony, z których tradycyjnie przybywa najwięcej kobiet, natomiast imigranci z większości krajów afrykańskich i azjatyckich to przede wszystkim mężczyźni ${ }^{7}$. Cudzoziemcy spoza krajów Unii stanowią grupę relatywnie młodą: dane z 2011 roku wskazują, że ponad połowa mieści się w przedziale wiekowym 25-44 lata. Około 18\% stanowi młodzież poniżej 16. roku życia. Oznacza to, że więcej niż 80\% imigrantów mieszkających aktualnie w Hiszpanii jest w wieku produkcyjnym. Wśród cudzoziemców z krajów trzecich (należących do tzw. Régimen General, systemu obejmującego obywateli spoza UE), odsetek osób powyżej 65. roku życia jest bardzo niski: zaledwie 1,36\%. Średni wiek imigranta spoza UE to 32 lata. Jest on o 5 lat niższy niż średnia wieku dla cudzoziemców z krajów Unii („Extranjeros residentes en España...”, 2011). Podsumowując, imigranci spoza UE są obecnie w Hiszpanii zdecydowanie młodszą populacją niż cudzoziemcy z krajów UE i autochtoni - Hiszpanie.

Jeżeli chodzi o obszary zatrudnienia imigrantów, do czasów ostatniego kryzysu ekonomicznego najczęściej podejmowali oni prace w sektorze usług (prawie 60\%), w budownictwie (ok. 20\%), nieco mniej w przemyśle (12\%) i rolnictwie (8\%). Imigrację w Hiszpanii charakteryzuje też specyficzne zróżnicowanie etniczno-zawodowe: obywatele państw członkowskich UE najczęściej pracują w sektorze finansów, w handlu lub wykonują wolne zawody. Latynosi tradycyjnie byli zatrudniani w branży hotelarskiej lub w sektorze prac domowych. Obywatele z Europy Wschodniej w większości zajmują się natomiast pracami w branży budowlanej (INE, 2011).

\section{・...}

5 Polacy plasują się dopiero na 19. miejscu pośród 20 najliczniej reprezentowanych grup imigranckich w Hiszpanii (85 862, co stanowi 1,5\% ogółu cudzoziemców).

6 Raport Avance del Padrón municipal a 1 de enero de 2011 (INE, 2011) oraz dokument Revisión del Padrón municipal 2001. Población extranjera por sexo, país de nacionalidad y edad opracowany przez Instituto Nacional de Estadística, www.ine.es (INE, b.d.).

7 Według danych Observatorio Permanente de la Inmigración z grudnia 2011 r., wśród imigrantów z kontynentu afrykańskiego ponad $62 \%$ stanowią mężczyźni. Przeważają także pośród cudzoziemców pochodzących z Azji (ponad 57\%) i Oceanii (ponad 58\%). Przewage kobiet odnotowano natomiast wśród przybyszów z krajów Ameryki Łacińskiej i Południowej (ponad 54\%) („Extranjeros residentes en España...”, 2011). 


\section{BOGACI EMERYCI I IMIGRANCI "ZAROBKOWI" - RÓŻNE OBLICZA IMIGRACJI W HISZPANII}

Imigranci w Królestwie Hiszpanii stanowią zróżnicowaną grupę zarówno pod względem kraju pochodzenia, jak i motywacji związanych z przyjazdem na ziemie Półwyspu Iberyjskiego. Na początku, w latach 80. XX wieku, do Hiszpanii przyjeżdżali głównie zamożni emeryci z innych krajów europejskich, szukający dogodnego zakątka, w którym chcieli w atrakcyjny sposób spędzić „jesień życia”. Najczęściej osiedlali się w Andaluzji oraz na hiszpańskich wyspach (Nalewajko, 2004, s. 27). Emeryci z Wielkiej Brytanii ${ }^{8}$ czy Niemiec, urzeczeni hiszpańskim klimatem i stylem życia, przez lata kupowali nieruchomości w Andaluzji, na Balearach czy Wyspach Kanaryjskich.

Ojczyzna Don Kichota, corridy i flamenco przyciągała również przedstawicieli innych kategorii wiekowo-zawodowych z bogatych krajów UE: biznesmenów pracujących "na odległość" czy ludzi wykonujących różnego rodzaju wolne zawody. Od lat 90. XX wieku do 2009 roku Hiszpania była równie atrakcyjną metą dla imigrantów zarobkowych. Można wyodrębnić kilka faz przyjazdów imigrantów z różnych zakątków świata: w latach 90. przeważali jeszcze cudzoziemcy z krajów zachodnich oraz Marokańczycy. Lata 2000-2004 to okres napływu tzw. andinos - Latynosów z obszarów andyjskich. Od 2005 roku zanotowano wzrost liczby przyjezdnych z Europy Środkowo-Wschodniej (Sven-Reher \& Requena, 2009, ss. 294-295).

Od lat 2000 hiszpańska gospodarka odnotowywała stały wzrost, na okres 2004-2005 przypadł czas największego boomu w sektorze budowlanym i branży turystycznej. Te dwa obszary były ze sobą powiązane: wzrost popularności Hiszpanii jako celu turystyki wiązał się z koniecznością rozbudowy infrastruktury turystyczno-rekreacyjnej. Wybrzeża hiszpańskie pokrywała rozrastająca się siatka hoteli, apartamentów, centrów handlowousługowych i innych obiektów przydatnych turystom podczas wakacyjnego wypoczynku. Boom w sektorze budowlanym oznaczał więc zapotrzebowanie na siłę roboczą ${ }^{9}$. Ogromnej rzeszy przyjezdnych z krajów Ameryki Łacińskiej i Południowej Hiszpania jawiła się jako kraj podobny pod względem kulturowym, a niekwestionowanym czynnikiem „przyciągania" (pull factor) dla Latynosów był język hiszpański. Co prawda latynoskie warianty języka hiszpańskiego różnią się - zarówno pod względem słownictwa, jak i akcentu - od obowiązującego w Hiszpanii kastylijskiego, jednak podobieństwo językowe zdecydowanie ułatwia odnalezienie się w nowych warunkach i zespolenie ze społeczeństwem przyjmującym. Niemniej w niektórych przypadkach to podobieństwo kulturowe może być paradoksalnie przeszkodą w integracji ze społecznością lokalną. Od przedstawicieli różnych organizacji latynoskich w Barcelonie zdarzało mi się słyszeć, że imigranci z Ameryki Łacińskiej dość niechętnie uczą się katalońskiego, ponieważ uważają, że znając hiszpański mają ułatwioną komunikację z autochtonami i są „przygotowani” do aktywnego uczestnictwa w społeczeństwie przyjmującym. Tymczasem nieznajomość katalońskiego może być sporym utrudnieniem, przede wszystkim na rynku pracy. Grupy latynoskie są co prawda pod wieloma względami bliskie kulturze Hiszpanii, ale z drugiej strony ich ogromna liczebność i wewnętrzna konsolidacja może utrudniać integrowanie się z miejscowymi (Sven-Reher \& Requena, 2009, s. 14).

Brytyjczycy stanowią grupę wyróżniającą się pod względem wiekowym: podczas gdy na ogół cudzoziemców przebywających w Hiszpanii przypada około 3,8\% osób powyżej 65. roku życia, w przypadku obywateli brytyjskich ten odsetek wynosit w 2010 roku aż 27\% (Pérez de Pablos, 2010).

9 O okresie hiszpańskiej prosperity do czasów ostatniego kryzysu pisze ciekawie G. De la Dehesa (2009). 
Dla imigrantów z krajów Maghrebu, szczególnie dla Marokańczyków, przy podejmowaniu decyzji o migracji do Hiszpanii szczególnie istotna jest bliskość geograficzna. Przedostanie się z wybrzeża marokańskiego do Andaluzji oznacza przepłynięcie cieśniny Gibraltarskiej (to właśnie w regionie Andaluzji odnotowuje się największą liczbę imigrantów z Maroka). Ale dróg przejścia na terytorium Hiszpanii jest więcej: na terenie ziem Maroka przebiegają granice z hiszpańskimi terytoriami Ceuty i Melilli. Stosunkowo niewielka jest również odległość z zachodniego wybrzeża Afryki do Wysp Kanaryjskich. Pogranicze hiszpańsko-marokańskie (najwyraźniej chyba widoczne na przykładzie fizycznej granicy z Ceutą i Melillą) wskazuje na ogromne dysproporcje społeczno-ekonomiczne na styku Europy i Afryki.

\section{KONSEKWENCJE IMIGRACJI DLA HISZPANII}

Stały napływ cudzoziemców i ich funkcjonowanie w społeczeństwie hiszpańskim przyczyniło się do jego istotnych przemian w ostatnich dekadach. Zmiany można zauważyć między innymi w wymiarze demograficznym. Obecność cudzoziemców przełożyła się (w latach poprzedzających aktualny kryzys) na wzrost populacji. Między 1998 i 2005 r. populacja Hiszpanii wzrosła o ponad 4,2 mln mieszkańców (ponad 10\% wzrost liczby ludności w ciągu 7 lat) (INE, 2012b). W ostatnich latach zapaści gospodarczej pojawiają się dane dotyczące spadku liczny urodzeń wśród kobiet imigrantek ${ }^{10}$.

Imigracja ma także swoje implikacje na gruncie ekonomicznym. Jak podają statystyki, w latach 2001-2005 około 45\% wpływów do kasy hiszpańskiej Seguridad Social (odpowiednik polskiego ZUS-u) pochodziło od imigrantów. Tym samym imigranci spowodowali wzrost hiszpańskiego PIB (producto interno bruto, czyli PKB) o 3\%. Od pracujących legalnie imigrantów pochodziła też znacząca część podatków wpływających do kasy państwa ${ }^{11}$. W okresie boomu gospodarczego imigranci wnieśli swój wkład w rozwój sektora turystycznego, budowlanego czy rolniczego. Dzięki cudzoziemcom Hiszpania odnotowała także wzrost przedsiębiorczości ${ }^{12}$. Konsekwencje ekonomiczne imigracji powodują również skutki postrzegane jako negatywne dla społeczności autochtonicznej: dumping płacowy (podejmowanie pracy za minimalne wynagrodzenie), stwarzanie konkurencji o stanowiska pracy, szczególnie te wymagające mniejszych kwalifikacji, sytuujące się na dole hierarchii pożądanych zawodów. Analizując zmiany na rynku pracy, warto wspomnieć o roli, jaką odgrywają kobiety imigrantki dla autochtonek: przejmując za nie część obowiązków związanych z utrzymaniem domu i opieką nad dziećmi oraz osobami starszymi i potrzebującymi, umożliwiają hiszpańskim kobietom awans zawodowy, rozwój kariery czy po prostu podjęcie pracy zawodowej poza domem. Dzięki pracy imigrantek Hiszpanki mogą zrealizować swoje potrzeby związane z własnym rozwojem, podejmować nowe wyzwania i konkurować z mężczyznami o lepsze stanowiska pracy (Romaniszyn, 2002, s. 24).

Imigranci w społeczeństwie hiszpańskim przynoszą także interesujące zmiany na poziomie społeczno-kulturowym. Stają się obiektem zainteresowania polityków, stwarzają potrzebę ciągłego udoskonalania i rewidowania polityki migracyjnej, wdrażania odpowied-

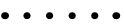

10 Zob. Salas, 2010.

11 Prognozę hiszpańskiego Ministerstwa Pracy i Spraw Społecznych dotyczącą możliwego wpływu imigracji na system emerytalny w Hiszpanii można znaleźć w dokumencie El efecto de la inmigración en la sostenibilidad a medio y largo plazo del sistema de pensiones en España („El efecto de la inmigración...”, b.d.).

$12 \mathrm{Na}$ temat imigranckiej przedsiębiorczości w Hiszpanii zob. m.in. A. Riesco Sanz (2008). 
nich programów integracyjnych. Powodują, że pojawiają się nowe wyzwania w dziedzinie edukacji międzykulturowej: drugie pokolenie imigrantów (czyli dzieci cudzoziemców urodzone w Hiszpanii) oraz tak zwane „pokolenie 1,5” (młodzi cudzoziemcy przybyli do Hiszpanii w wieku kilku lat i wychowani już w nowym środowisku) staje się coraz istotniejszym elementem hiszpańskiego społeczeństwa (Portes, Aparicio, \& Haller; 2009; Aparicio Gomez, 2007). Te nowe dwujęzyczne (a czasem kilkujęzyczne) społeczności, które można za A. Kłoskowską (1996) nazwać jednostkami biwalentnymi czy poliwalentnymi kulturowo, będą w niedalekiej przyszłości stanowić o profilu populacji zamieszkującej Hiszpanii.

\section{POWÓDŹ, LAWINA, ZALEW - JĘZYK HISZPAŃSKICH MEDIÓW W ODNIESIENIU DO IMIGRACJI}

Dane statystyczne dotyczące życia i pracy imigrantów w Hiszpanii oraz „policzalne” konsekwencje ich pobytu wynikające z różnego rodzaju oficjalnych zestawień często nie pokrywają się z wizerunkiem medialnym rozpowszechnianym przez telewizję i prasę. A to właśnie ten obraz medialny wywiera znaczący wpływ na opinie, postawy i zachowania hiszpańskiego społeczeństwa względem cudzoziemców. Funkcjonujący obecnie portret imigranta różni się od jego społecznego wyobrażenia z lat 80. XX wieku, kiedy "nie istniała powszechna opinia na temat imigranta, uważano go po prostu za turystę (biały, blondyn, wysoki i z pieniędzmi). Cudzoziemiec nie kojarzył się z tymczasowym imigrantem; ten obraz kształtuje się później" (De Prada, Actis, \& Pereda, 2002, s. 26). Terminologia oraz styl wypowiedzi stosowane przez hiszpańskie media w odniesieniu do imigrantów zasługują rzecz jasna na osobne szczegółowe opracowanie. Warto jednak wspomnieć w tym miejscu o kilku tendencjach, charakterystycznych dla hiszpańskiego przekazu medialnego na temat imigracji. Badacze mediów, socjologowie i sami dziennikarze zwracają uwagę na często alarmistyczny ton wypowiedzi, przewage informacji negatywnych oraz wiadomości o charakterze „prewencyjnym” (jak ustrzec się przed niebezpieczeństwami powodowanymi przez imigrantów). Podkreśla się obsesyjne wiązanie kwestii migracyjnych z hasłami takimi, jak: niebezpieczeństwo, przemoc, problem. Nagminne jest również nadużywanie odwołań do narodowości przestępcy, jeżeli jest on cudzoziemcem (np. tytuł "Albańczyk zabił dziecko" może być dobrym przykładem takiej tendencji). Przekazy medialne budują poprzez to klimat niepewności, "skrytości i utajniania” (ocultamiento). Powracającym wątkiem jest również kwestia przenoszenia egotycznych chorób przez cudzoziemców ${ }^{13}$. Mimo że według statystyk najwięcej imigrantów przybywa współcześnie do Hiszpanii samolotami (Sven-Reher \& Requena, 2009, s. 309) media skupiają się przede wszystkim na tych, którzy w dramatycznych warunkach przybijają do brzegów Półwyspu Iberyjskiego na tratwach i prowizorycznych łodziach. Z punktu widzenia środków masowego przekazu jest to najbardziej spektakularny i „medialny” zarazem sposób przedostania się na teren Hiszpanii i chociaż dotyczy niewielkiego odsetka imigrantów, media wyolbrzymiają to zjawisko. Ta emfaza staje się przyczyną manipulacji i deformacji wizerunku imigranta. Metafory, których hiszpańscy dziennikarze używają, pisząc o tych przypływających na tratwach i pontonach cudzoziemcach, odnoszą się najczęściej do kataklizmów i żywiołów, a także zjawisk atmosferycznych. „Uderzenie fali", „lawina”, „powódź”, "zalew" (oleadas, avalancha, alud) to najczęściej stosowane porównania. Kolejnym powtarza-

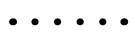

13 Wszystkie te wątki porusza w swojej ciekawej analizie M. Lario Bastida (2005). 
jącym się problemem jest nadużycie słowa „nielegalny” (ilegah), które jednoznacznie kojarzy się z przestępczością i wzmacnia stereotypowe skojarzenia z imigrantem "tamiącym prawo". Tymczasem najczęściej jedynym wykroczeniem (a nie przestępstwem) popełnianym przez tych cudzoziemców jest nieposiadanie odpowiednich dokumentów uprawniających do wjazdu na teren kraju. Pisze się o „przechwytywaniu” imigrantów (interceptar), co kojarzy się raczej z przejmowaniem przemycanego towaru. O łodziach przewożących imigrantów mówi się barco negrero - używając terminu (negrero), który w czasach kolonialnych oznaczał „,handlującego Murzynami”. W takim kontekście represyjne działania hiszpańskiej straży nabrzeżnej i policji względem przybyszów na łodziach pokazuje się jako akcje „wyzwoleńcze”, uwalniające ich z rąk złych przewoźników, którzy zorganizowali im transport w uwłaczających warunkach (Aierbe, 2007).

\section{KONSEKWENCJE KRYZYSU DLA IMIGRANTÓW I SPOLECZEŃSTWA. WYBRANE OPINIE Z HISZPAŃSKIEJ PRASY}

Jesienią 2008 roku, czyli w okresie bezpośrednio poprzedzającym nadejście poważnego załamania gospodarczego, pojawił się ciekawy artykuł dotyczący wpływu kryzysu ekonomicznego na imigrację w Hiszpanii. W tytule tekstu autor ironicznie wyraził ówczesne nastawienie hiszpańskiego społeczeństwa do cudzoziemców: „Dziękujemy za wszystko, ale proszę sobie już iść" (Ariza, 2008). Autor tekstu przypomniat, że w latach dobrobytu i rozwoju gospodarczego dyskurs publiczny na temat imigracji zdominowały pozytywne aspekty obecności cudzoziemców w Hiszpanii. Ówczesny socjalistyczny rząd, wraz z organizacjami pozarządowymi i przy wtórze czołowych przedstawicieli świata akademickiego, usilnie starał się przedstawiać imigrację w pozytywnym świetle, traktując ją jako konstytutywny składnik hiszpańskiej gospodarki. Mówiono, że pracujący imigrant przyczynia się do wzrostu gospodarczego, a regularnie płacąc składki ubezpieczeniowe i emerytalne, zabezpiecza przyszłość starszego pokolenia Hiszpanów. Poza tym, przejmuje od autochtonów niechętnie wykonywane prace, a do tego skutecznie odmładza populację Hiszpanii. Imigrację uważano za konieczną i przede wszystkim użyteczną dla społeczności lokalnych.

Powiązanie imigrantów z „przydatnością" znajdowało swoje potwierdzenie w danych demograficznych i wskaźnikach ekonomicznych. W latach 1994-2006 populacja Unii Europejskiej wzrosła o $19 \mathrm{mln}$ osób, z czego $15 \mathrm{mln}$ stanowili imigranci. W Hiszpanii imigracja wzrastała 10 razy szybciej, niż wynosit przyrost populacji autochtonicznej. Gdyby nie cudzoziemcy, hiszpański PKB w ciągu dekady 1995-2005 zmalałby o 0,6\%, tymczasem zanotowano jego wzrost o 2,6\% właśnie dzięki pracy imigrantów (Ariza, 2008). Silny kryzys przetaczający się przez Europę i dotkliwie doświadczający Hiszpanię sprawit, że owo rozumowanie zeszło na dalszy plan. Gwałtowny wzrost bezrobocia, inflacja, zadłużenie państwa, spadek konsumpcji - te wszystkie zjawiska wyznaczane przez twarde dane liczbowe powodują, że imigrant przestaje być traktowany jako źródło bogactwa, czy konieczne dla rozwoju społeczno-gospodarczego „zasoby” (recurso). Staje się kozłem ofiarnym, którego można obarczyć winą i odpowiedzialnością za niepowodzenia, wyrzeczenia, przeciwności w trudnych czasach. Recesja hiszpańskiej gospodarki wzięła swój początek W załamaniu się sektora budowlanego i rynku nieruchomości. W połowie roku 2007 roku zanotowano 36492 nowych bezrobotnych, z czego 21\% stanowili cudzoziemcy. Recesję na rynku pracy imigrantów potwierdzał też spadek oszczędności wysyłanych przez nich do krajów pochodzenia (remesas). 
Warto w tym miejscu przypomnieć o rozróżnieniu na „imigrantów” (kojarzonych zazwyczaj z obywatelami państw spoza UE) i „cudzoziemców” będących obywatelami unijnymi ${ }^{14}$. Poczucie zagrożenia wiąże się oczywiście jedynie z tą pierwszą grupą, co podkreślają ugrupowania polityczne o zabarwieniu nacjonalistycznym. Cudzoziemca spoza UE (extranjero no comunitario) przedstawia się zwykle w powiązaniu z bezrobociem, przestępczością, obarczając go winą za nadużywanie systemu opieki społecznej i pozbawianie rodowitych Hiszpanów dostępu do świadczeń socjalnych. Media epatują obrazami ukazującymi tragiczne wypadki z udziałem imigrantów, mówiąc np. o utonięciach setek osób próbujących przedostać się z Afryki na terytorium Wysp Kanaryjskich (w 2006 roku zaginęło w ten sposób 920 osób). Jak pisze Ariza, „kryminalizacja imigranta staje się codzienną i akceptowaną strategią" (Ariza, 2008). Imigrant, konstatuje ironicznie autor, wypełnił już swoją rolę. A ponieważ jest już nie tylko nieprzydatny, ale stanowi ciężar, należy się go pozbyć. Korzysta się przy tym z dwóch możliwości: wydalenia lub skłonienia go dobrowolnego powrotu w ramach przygotowanych przez państwo programów ${ }^{15}$ (Ariza, 2008). Ograniczanie napływu imigrantów to także bardziej rygorystyczne przeprowadzanie akcji „regularyzacyjnych" (tzn. legalizowania pobytu nielegalnych imigrantów), większe restrykcje w przypadku tzw. „łączenia rodzin” (reagrupación familiar), a także bardziej skomplikowane i dłuższe procedury przedłużania pozwolenia na pobyt i wydania wiz.

W połowie 2009 roku za dwie najbardziej poszkodowane przez kryzys społeczności w Hiszpanii uznano Ekwadorczyków i Marokańczyków. Według raportu "Inmigración y Mercado de Trabajo"16 zaprezentowanego przez El Observatorio Permanente de la Inmigración ${ }^{17}$, imigranci dużo dotkliwiej niż autochtoni odczuli pierwszą falę recesji ${ }^{18}$. Pod koniec 2008 roku odsetek bezrobotnych Marokańczyków wyniósł w Hiszpanii 35\%, co znacznie przewyższało zarówno odsetek wszystkich bezrobotnych imigrantów, jak i odsetek bezrobocia dla całego społeczeństwa. W przeciwieństwie do społeczności rumuńskiej, w której wzrost bezrobocia spowodowany był przede wszystkim napływem nowych obywateli, w przypadku Marokańczyków odzwierciedlało to sytuację osób, które przebywały już wcześniej na terytorium Hiszpanii i stracity pracę. Ekwadorczycy byli natomiast grupą, która najbardziej ucierpiała na utracie przynależności do Seguridad Social, czyli hiszpańskiego systemu ubezpieczeń społecznych. Z powodu sytuacji kryzysowej w 2009 roku wprowadzono specjalną usługę darmowej pomocy psychologicznej dla Marokańczyków przebywających w Hiszpanii w ramach programów łącznia rodzin. Uznano wówczas, że imigranci marokańscy są w Hiszpanii dużo gorzej zintegrowani niż w innych miejscach Europy. We wspomnianym raporcie „Imigracja i Rynek Pracy” pojawiła się również prognoza, że w ciągu kolejnych lat w Hiszpanii będą się nasilać tendencje ksenofobiczne

\section{......}

14 Rozróżnienie to wprowadzają m.in. cytowani już Sven-Reher i Requena (2009, ss. 13-14).

15 Plan de Retorno Voluntario para Residentes en Paro - plan powrotu dla bezrobotnych imigrantów zaproponowany przez socjalistyczny rząd Zapatero przewidywał wypłacenie całej należności z tytułu bezrobocia w dwóch ratach, pod warunkiem niepowracania na terytorium Hiszpanii przez minimum trzy lata.

16 "Imigranci i rynek pracy" (Pajares, 2009).

17 "Komórka hiszpańskiego Ministerstwa Pracy na bieżąco monitorująca sytuację imigrantów w kraju http://extranjeros.meyss.es/es/ObservatorioPermanentelnmigracion/ (Observatorio Permanente de la Inmigración, 2011).

18 Por. interesujące studium na temat wpływu kryzysu ekonomicznego na położenie nielegalnych imigrantów w Hiszpanii: C. Manzanedo, R. Gonzalez Fabre, Impacto de la crisis económica sobre los inmigrantes irregulares en España (Manzanedo \& Gonzalez Fabre, 2009). Autorzy analizują sytuację w latach 2007-2009, przewidując, że w 2010 roku bezrobocie w Hiszpanii sięgnie 20\%. Prezentując sytuacje na rynku pracy w ostatnich dwóch latach przed pierwszą falą kryzysu, pokazują, że problem utraty pracy dotyczył w dużo większym stopniu imigrantów z nieuregulowanym pobytem. W sytuacji zagrożenia bezrobociem Hiszpanie przestali tolerować ich prace „na czarno" W rolnictwie, budownictwie czy sektorze usługowym. Brak możliwości przedłużenia pozwolenia na pobyt spowodował też przejście wielu legalnych imigrantów do kategorii „irregulares" (Manzanedo \& Gonzalez Fabre, 2009, ss. 4-7). 
względem imigrantów (Sanmartín, 2009). Przewidywania te potwierdza 400-stronicowy raport "Evolución del racismo y de la xenofobía en España" (Ewolucja rasizmu i ksenofobii w Hiszpanii) z 2009 roku, przygotowany przez Observatorio del Racismo y de la Xenofobía - agendę informacyjno-badawczą hiszpańskiego Ministerstwa Pracy i Imigracji. W raporcie prezentowane są opinie 2800 Hiszpanów, z których 37\% jest "przeciwnych" imigracji, 33\% jest względem niej „tolerancyjnych”, a 30\% prezentuje poglądy "ambiwalentne". Dla $42 \%$ badanych aktualne prawo regulujące przyjazdy i pobyt imigrantów w Hiszpanii jest „zbyt tolerancyjne”; jedynie 5\% uważa funkcjonujące przepisy za „raczej surowe"19

W 2010 roku hiszpańska prasa pisała, że na skutek kryzysu Hiszpania staje się coraz mniej atrakcyjna dla imigrantów, a zwłaszcza dla obcokrajowców nieposiadających pozwolenia na pobyt, czyli wedle hiszpańskiego prawa przebywających na terenie kraju nielegalnie. Miało to związek z recesją w tych obszarach gospodarki, w których ci imigranci najczęściej podejmowali pracę, czyli przede wszystkim w sektorze budownictwa. Grupy imigranckie o najwyższym odsetku osób sin papeles (potoczne określenie imigrantów nieposiadających uregulowanego statusu) to w 2010 roku przede wszystkim Boliwijczycy, Paragwajczycy, Brazylijczycy, Wenezuelczycy i Argentyńczycy (Cepada, 2010). Według obserwacji socjologa z Uniwersytetu Compultense, Joaquína Arango ${ }^{20}$, wyjazd z kraju imigracji i powrót do ojczyzny nie jest jedyną strategią podejmowaną przez cudzoziemców w obliczu recesji. Wielu z nich próbuje utrzymać się na rynku pracy mimo wzrastającego bezrobocia, przekwalifikowując się i szukając zatrudnienia w innej dziedzinie. Boliwijczycy odchodzą z sektora rolniczego i próbują swoich sił w obszarze prac domowych, pomocy w gospodarstwie ${ }^{21}$. Chińczycy zakładają natomiast własne firmy, przechodząc do branży handlowej: sprzedaży hurtowej i handlu zagranicznego (import-eksport towarów między Chinami i Hiszpanią). Jak zauważył Josep Oliver, ekonomista z Uniwersytetu Autonomicznego w Barcelonie, w 2009 roku napływ imigrantów wyraźnie stracił na sile: przyjechało jedynie 80000 osób, podczas gdy rok przed kryzysem (2008) zanotowano 480000 nowych przybyszów. Oliver jest jednak zdania, że imigranci zaczną znowu osiedlać się w Hiszpanii, choć z nieco mniejszą intensywnością: „Trendy demograficzne w kraju pokazują, że kiedy minie kryzys, będziemy mieć kolejną falę imigrantów, ale o odmiennym profilu: wykwalifikowanych młodych, a także kobiety w średnim wieku i na średnim poziomie kwalifikacji, które zaopiekują się naszą postarzałą populacją" (Cepada, 2010).

W maju 2010 roku dziennik „El País”, powołując się na dane hiszpańskiego Ministerstwa Pracy i Imigracji, podał, że kryzys hamuje przyrost liczby imigrantów w Hiszpanii (Pérez de Pablos, 2010). Jeszcze w 2007 roku ich liczba wzrosła o 7,6\%, rok później o 9,2\%, a w 2010 roku jedynie o 5,6\%. Autorka artykułu informuje, że zanotowano spadek liczby kart pobytu (hiszp. tarjeta de residencia) wydawanych obywatelom krajów trzecich (spoza UE). Zmniejszenie liczby wystawionych dokumentów zanotowano szczególnie w odniesieniu do Ekwadorczyków (w 2010 roku wydano im prawie 4000 mniej kart pobytu). Jednocześnie, jak podaje Observatorio Permanente de la Inmigración, temu zmniejszeniu liczby imigrantów spoza UE (no comunitarios) towarzyszył przyrost liczby cudzoziemców z krajów członkowskich Unii, zwłaszcza obywateli brytyjskich.

\section{......}

19 Zob. „La crisis dispara el rechazo a los inmigrantes" (2010). Cały raport dostępny jest na stronie Observatorio Español del Racismo y de la Xenofobía (b.d.), http://www.oberaxe.es/files/datos/4b26574eb2f66/ Informe2009.pdf LINK NIEAKTYWNY

20 W latach 2010-2012 Arango obejmowat także stanowisko przewodniczącego Forum Społecznego na rzecz Integracji Imigrantów, zob. „Foro para la integración social de los inmigrantes", b.d.

21 W ciągu roku hiszpańska Seguridad Social zanotowała 7000 nowych zgtoszeń ubezpieczeniowych dla Boliwijczyków pracujących w sektorze domestic service-prac domowych (Cepada, 2010). 
Według badań hiszpańskiego ośrodka badawczego Centro de Investigaciones Sociológicas (CIS, Centrum Badań Socjologicznych) przeprowadzonych w maju 2011 roku, trzema kwestiami, którymi najbardziej przejmowali się Hiszpanie, były kryzys $(84,1 \%)$, problemy ekonomiczne $(46,7 \%)$ oraz klasa polityczna $(22,1 \%)$. Biorąc pod uwagę aktualne problemy z zatrudnieniem w Hiszpanii, nie dziwi tak wysoki odsetek obawiających się o utratę pracy. Osiem na dziesięć badanych była zdania, że najprawdopodobniej oni lub ich bliscy w niedługim czasie stracą zatrudnienie. Prawie połowa bała się, że nie wystarczy im środków na utrzymanie rodziny. Interesujące, że wśród najbardziej palących kwestii, na czwartym miejscu znalazła się właśnie imigracja: jako problem postrzega ją 11,2\% respondentów. Hiszpanie obawiali się wówczas imigrantów bardziej niż terroryzmu i braku poczucia bezpieczeństwa obywatelskiego (po 7,2\%) (Gomez-Cotta, 2011). Kolejne sondaże z lutego 2012 roku wskazały na nieco inny obraz sytuacji. Pierwsze trzy „problemy" nie zmieniły się w znaczący sposób, przetasowaniu uległy kolejne problematyczne kwestie zauważane przez Hiszpanów. Na pytanie (wielokrotnego wyboru) o największy aktualny problem, z którym boryka się Hiszpania ${ }^{22}$, respondenci udzielili następujących odpowiedzi: bezrobocie (83,8\%), problemy ekonomiczne $(52,2 \%)$, klasa polityczna/partie polityczne $(19,4 \%)$, korupcja i malwersacje $(8,6 \%)$, brak bezpieczeństwa obywatelskiego (la inseguridad ciudadana, 6,6\%). Następnie edukacja (6,3\%) i imigracja (6,2\%). Problem terroryzmu wskazano jedynie w 1,7\% odpowiedzi, podczas gdy jeszcze w maju 2011 stanowit on 9,1\% wskazań (CIS, 2012, 2011).

Ciekawe, że jeszcze przed kryzysem, w lutym 2008 roku, sytuacja ta wyglądała zupełnie inaczej, całkiem inne były proporcje i „ważność" poszczególnych problemów nurtujących Hiszpanów. Wyniki były następujące: bezrobocie (44,6\%), problemy gospodarcze $(36,2 \%)$, terroryzm, ETA $(31,4 \%)$, mieszkanie $(28,9 \% 0$, imigracja $(27,3 \%)$ (CIS, 2008). Sytuacja zapaści gospodarczej sprawiła, że w 2012 r. na problemy z zatrudnieniem wskazywało dwukrotnie więcej Hiszpanów. Problem ogromnego wzrostu bezrobocia „zdeklasowat" więc wyraźnie kwestię imigracji. W obliczu marazmu ekonomicznego i problemów finansowych państwa relacje z imigrantami zostały zepchnięte na dalszy plan. Jest to trochę zastanawiające, zważywszy na fakt, że w dobie kryzysu i utrudnionego dostępu do dóbr (takich jak np. miejsce pracy), imigrant może się jawić przede wszystkim jako konkurent, ten który zabiera prace autochtonom. Natomiast kiedy nie pracuje i pobiera zasitek socjalny, jest postrzegany jako ciężar dla budżetu państwa. Kryzysy sprzyjają nasilonej stereotypizacji „obcych" i intensyfikowaniu się antagonizmów międzyetnicznych. Poprzez "kryminalizację Innego" i kreowanie „kozła ofiarnego" media tworzą portret wspólnego wroga, obarczanego odpowiedzialnością za niedogodności natury społeczno-ekonomicznej (Maneri, 2011, s. 78). Badania CIS nie potwierdziły jednak tej zależności.

W styczniu 2011 roku „El País” poinformowat, że liczba cudzoziemców spoza krajów UE zmniejszyła się o 6,5\% w ciągu pierwszych 9 miesięcy 2010 roku. Spadek zanotowano szczególnie w Madrycie oraz we Wspólnocie Autonomicznej Walencji. Autorzy przypominają jednocześnie, że największym skupiskiem imigrantów jest wciąż Barcelona i prowincja (19,45\% wszystkich imigrantów w Hiszpanii). W 2010 roku liczba bezrobotnych imigrantów z krajów trzecich wzrosła o 10\%, co oznaczało ponad 600000 osób bez pracy ( „Los extranjeros no comunitarios...", 2011).

W maju 2011 roku korespondentka BBC w Madrycie, Sarah Rainsford, napisała: „Kryzys wygania imigrantów z Hiszpanii" (Rainsford, 2011). Według danych INE wiosną 2011

22 W oryginale: Cuál es, a su juicio, el principal problema que existe actualmente en España? ¿Y el segundo? ¿Y el tercero? 
roku bezrobocie sięgnęło w Hiszpanii $21 \%$, z czego $32 \%{ }^{23}$ stanowili właśnie pracownicy imigranccy. W artykule opisano historię Nigeryjczyka Yousufa Akue Ouma, który przybył do Hiszpanii w 2005 roku, kiedy sytuacja gospodarcza była bardzo dobra, a "kraj był gigantycznym placem budowy" (Rainsford, 2011). Po dwóch latach satysfakcjonującej pracy Nigeryjczyk utrzymujący rodzinę $w$ kraju pochodzenia stracił zatrudnienie. Nie mając legalnej pracy, nie mógł starać się o przedłużenie pozwolenia na pobyt. Aby zdobyć środki na utrzymanie rodziny, zaczął prosić o jałmużnę na ulicy. Korespondentka BBC wyjaśnia, że to siła robocza z Ameryki Łacińskiej i Afryki w dużej mierze przyczyniła się do rozkwitu gospodarczego Hiszpanii. Imigranci, którym udało się znaleźć dobre zatrudnienie ściągali potem kolejnych członków rodziny. Zapaść ekonomiczna spowodowała radykalną zmianę ich położenia: nie mając pracy, tracą prawo pobytu, co naraża ich na wydalenie z Hiszpanii. Ich uregulowany dotychczas status radykalnie się zmienia: stają się irregulares, clandestinos, bez większych możliwości roszczenia swoich praw. Hiszpański oddział Caritas szacuje, że takich cudzoziemców dotkniętych tą "nagłą nielegalnością" (repentinamente irregulares) może być nawet do 800 000. Pracownicy Caritas obserwują coraz częstsze legitymowanie imigrantów, nawet w prowadzonych przez ten ośrodek stołówkach i jadłodajniach dla ubogich. Na tę sytuację skarżą się policjanci, którzy odczuwają silną presję władz dla zaostrzania procedur kontrolnych. José Manuel Sánchez Fornet, sekretarz generalny Sindicado Unificado de Policía (Związku Zawodowego Policjantów) przyznaje, że poziom nadzoru porównywalny jest do czasów reżimu generała Franco. Policjanci mają nieformalny nakaz od swoich przełożonych przeprowadzenia codziennie od 10-25 kontroli osobistych i inspekcji imigrantów, obojętnie, czy są o cokolwiek podejrzani. Tak jakby chodziło przede wszystkim o wypełnienie normy. Wielu byłych legalnych pracowników po utracie pracy stara się utrzymywać z dorywczych zajęć, np. sprzedając (bez oficjalnego pozwolenia) towary w metrze czy w miejskich parkach. Przyznają, że kiedyś nie było aż tak częstych kontroli, których teraz padają ofiarą. Podczas wizyty w barcelońskim Parku Güell w styczniu 2012 roku miałam okazję zobaczyć, jak wygląda taka policyjna "łapanka” wędrownych imigranckich sprzedawców. Nagły przyjazd policji powoduje dezorientację, a potem ucieczkę na oślep w jak najdalsze zakamarki parku. Imigranci w pośpiechu zwijają swój towar, a uciekając, często gubią po drodze przedmioty na sprzedaż. Nie wszystkim udaje się oddalić na czas, zazwyczaj jedna lub dwie osoby zostają zatrzymane przez policjantów, wylegitymowane i przeszukane na oczach zaciekawionych tym „lokalnym kolorytem" turystów.

Mówiąc o deportacjach nielegalnych imigrantów, należy zauważyć pewną tendencję: co prawda w 2010 roku hiszpańskie MSW zanotowało spadek liczby wydalonych, ale jednocześnie brakuje aktualnych danych na temat liczby osób przetrzymywanych w obozach w oczekiwaniu na wydalenie (campos de deportación), a także liczby wydanych nakazów deportacji (INE, 2012a). Trzeba dodać, że wielu cudzoziemców dobrowolnie decyduje się na powrót do kraju pochodzenia. Jeśli mogą, korzystają ze specjalnych programów rządowych (chodzi o rządy państw, z których przyjechali). Taką możliwość daje powrotnym migrantom m.in. rząd Ekwadoru24. Jednak kwestia pokrycia kosztów podróży powrotnej

23 Według najnowszych danych INE liczba ta stale wzrasta, zob. www.ine.es [dostęp: 30.03.2012].

24 W Hiszpanii powstają organizacje i programy wspomagające dobrowolne powroty Ekwadorczyków (a także innych imigrantów) do kraju pochodzenia, jak np. Secretaría Nacional del Migrante (Senami), pomagająca migrantom powrotnym zorganizować na nowo swoje życie, powrócić do aktywności wykonywanej przed wyjazdem do Hiszpanii albo przekwalifikować się i dostosować swoje umiejętności do nowych wymagań rynku pracy, zob. http://www.senami.gob.ec/proyectos.html. Częstą strategią stosowaną przez Ekwadorczyków jest także wyjazd z Hiszpanii do innego kraju UE, najczęściej do Wielkiej Brytanii, por. „España tiene más inmigrantes a pesar de la crisis" (2011). 
to rozwiązanie tylko jednego z wielu problemów. Dla cudzoziemców, którzy od lat mieszkali i pracowali w Hiszpanii, powrót do kraju oznacza ponowną emigrację. Dla ich dzieci, urodzonych i wychowanych w społeczeństwie hiszpańskim, wyjazd do kraju rodziców jest często podróżą do niemal obcego miejsca, znanego jedynie z opowieści albo ze sporadycznych wizyt rodzinnych, nierealnego i często wręcz mitycznego. Niektórzy więc mimo fatalnej sytuacji i niepewnej przyszłości chcą pozostać w Hiszpanii: kolejki do biur pracy (zasilane głównie przez cudzoziemców) stały tam się nieodłączną częścią miejskiego krajobrazu.

Jedną z zauważanych „strategii wyjścia” z kryzysu jest dalsza emigracja za ocen. Według analiz przeprowadzonych w 2011 roku przez Randstad - agencję doradztwa personalnego i pracy tymczasowej - 65\% imigrantów nieposiadających legalnej pracy w Hiszpanii brało pod uwage wyjazd poza Europe, o ile nie znajdzie zatrudnienia do 2012 roku. Co więcej, o opuszczeniu własnego kraju myślą także sami Hiszpanie: według sondażu Randstad z 2012 roku 65\% młodych hiszpańskich obywateli (w wieku 18-25 lat) chce wyjechać za granice w poszukiwaniu pracy („Un 65\% de los jóvenes españoles...", 2012). Saldo migracyjne w Hiszpanii było w 2010 roku negatywne, po raz pierwszy od 35 lat. Oznacza to, że więcej osób (aktywnych i dorosłych) wyjechało z kraju, niż do niego przyjechało (Infante, 2011) ${ }^{25}$. Według prognozy Fundación Estudios de Economía Aplicada (Fundacji Studiów nad Ekonomią Stosowaną), jeżeli kryzys się utrzyma, w 2014 roku może przyjechać do Hiszpanii jedynie 3000 imigrantów. „El País” alarmuje, że w ciągu najbliższej dekady hiszpańska populacja zmniejszy się o pół miliona, o ile utrzyma się aktualna tendencja demograficzna (spadek urodzeń, wyjazdy autochtonów i uszczuplenie napływu imigrantów) („España perderá medio millón de habitantes...", 2011; INE, 2012b).

Hiszpania traci swoją atrakcyjność przede wszystkim dla pracowników nisko wykwalifikowanych. Hiszpański sektor budowlany i usługowy były dwoma obszarami, w których tradycyjnie znajdowali zatrudnienie. Kryzys ostatnich lat diametralnie zmienit te sytuację. Między 2008 i 2010 rokiem upadło ponad 200000 firm i przedsiębiorstw działających w sektorze budowlanym, a to one dawały możliwość pracy dla około 70\% Latynosów („España perderá medio millón de habitantes...”, 2011; INE, 2012b). Najpopularniejszymi kierunkami dalszej emigracji z Hiszpanii jest współcześnie Brazylia, wraz ze Stanami Zjednoczonymi i Argentyną. Brazylia przyciąga przede wszystkim ze względu na stabilną sytuację polityczno-ekonomiczną, choć ankietowani planujący tam wyjazd obawiają się braków w systemie opieki społecznej. Według danych sondażu przeprowadzonego przez Adecco i Uniwersytet w Nawarze, dynamicznie rozwijająca się Brazylia jawi się jako dobre miejsce emigracji dla osób z wysokimi kwalifikacjami, głównie w dziedzinie inżynierii i nauk ścisłych ${ }^{26}$.

Pod koniec listopada 2011 roku dziennik „El Mundo” opublikował dane statystyczne dotyczące aktualnych trendów migracyjnych w Hiszpanii („Los latinoamericanos 'abandonan' España...", 2011) w odwołaniu do raportu opracowywanego cztery razy w roku przez departament podlegający pod Ministerstwo Pracy i Imigracji27. W tytule artykułu podano: "Latynosi opuszczają Hiszpanię z powodu kryzysu i bezrobocia". Jak wskazały rezultaty ba-

\section{-....}

25 W 2010 roku przyjechało do Hiszpanii 48000 imigrantów, a 43000 cudzoziemców powróciło do swego kraju pochodzenia. Trzeba jednak do tego rachunku dodać 90000 Hiszpanów, którzy wyjechali za granicę w poszukiwaniu pracy (Infante, 2011).

26 Brazylię jako kraj możliwej emigracji wybierają najczęściej młodzi Hiszpanie, mężczyźni w wieku 25-35 lat, posiadający wykształcenie i doświadczenie zawodowe w dziedzinie: inżynierii, architektury, informatyki, medycyny albo nauk biologicznych. Jak podaje Instituto Nacional de Estadística, w styczniu 2011 roku było 92260 Hiszpanów mieszkających w Brazylii. W roku 2010/11 ich liczba wzrosła o 10 071. (INE, 2012b).

27 Secretaría de Estado de Inmigración y Emigración, Extranjeros residentes en España. Principales resultados (Secretaría de Estado de Inmigración y Emigración, b.d.) 
dań, w trzecim trymestrze 2011 roku zmniejszyła się liczba Ekwadorczyków, Kolumbijczyków, Peruwiańczyków, Kubańczyków i Argentyńczyków mieszkających w Hiszpanii. Najwyraźniej widać ten trend na przykładzie obywateli z Ekwadoru - od kilku lat najliczniejszej pozaeuropejskiej grupy imigranckiej w Hiszpanii. Raport wskazuje także na względną równowage jeśli chodzi o proporcje cudzoziemców z innych krajów członkowskich Unii i tych spoza UE (odpowiednio 48,46\% dla obywateli UE i 51,54\% dla extracomunitarios). Madryt i Barcelona to prowincje o największej liczbie obywateli z krajów UE. Za nimi plasują się Alicante, Valencia, Malaga i Baleary. Jednocześnie Barcelona jest miastem, w którym mieszka najliczniejsza grupa imigrantów z krajów trzecich. Dane z raportu pokazują spadek liczby czasowych (krótszych) pozwoleń na pobyt i jednocześnie przewagę dokumentów wydawanych na dłuższy okres (larga duración). Zauważalna jest także względna równowaga między liczbą kobiet i mężczyzn ${ }^{28}$. Pod tekstem, na forum gazety jeden z czytelników podsumował prezentowane dane w następujący sposób: „Poziom nienawiści do cudzoziemców jest wprost proporcjonalny do liczby bezrobotnych, ilości imigrantów i do braku kultury w kraju" („Los latinoamericanos 'abandonan' España...”, 2011).

\section{INNE SPOJRZENIE NA PROBLEM: "DEMONTAŻ” MITÓW NA TEMAT KRYZYSU I IMIGRANTÓW W HISZPANII}

Ciekawy głos w dyskusji na temat konsekwencji kryzysu dla sytuacji imigrantów w Hiszpanii pojawił się wiosną 2011 w gazecie „El Mundo” (Sanmartín, 2011): w jednym z artykułów wykazano bezzasadność popularnych w hiszpańskim społeczeństwie przekonań na temat wpływu kryzysu na cudzoziemców. Jego autorka, Olga Sanmartín, obala pewne mity i stereotypy związane z tym problemem, odwołując się przy tym do rocznika wydawanego cyklicznie przez Secretaría de Estado de Inmigración y Emigración (Krajowy Sekretariat Imigracji i Emigracjii ${ }^{29}$, powstałego przy współpracy wielu ekspertów do spraw migracji (Aja, Arango, \& Oliver, 2010) ${ }^{30}$. Rocznik odnosi się przede wszystkim do impasu gospodarczo-społecznego, o czym wzmiankuje już sam jego tytut: „Imigracja i kryzys ekonomiczny: stan obecny i perspektywy na przyszłość". Jego autorzy dokonują swoistego „demontażu” utartych szablonów, a z ich analizy można wyciągnąć kilka gtównych wniosków. Przyjazdy imigrantów do Hiszpanii zostały w ostatnich trzech latach wyraźnie ograniczone, fale migracyjne ustały, ale nie oznacza to, że kryzys „wygnał" cudzoziemców. Recesja nie spowodowała masowych wyjazdów, czego powszechnie się spodziewano. Socjolog Joaquín Arango, jeden z redaktorów rocznika wskazuje, że niewiele osób powrócito do kraju pochodzenia, a ogromna większość zdecydowała się na pozostanie w Hiszpanii. „I tutaj pozostaną" - dodaje Arango, wyliczając, że imigracja wciąż jest ważnym elementem strukturalnym hiszpańskiego społeczeństwa. Kryzys w żaden sposób nie wpłynął na ważność imigracji i jej range jako fenomenu społecznego: to cały czas około

28 Pośród obywateli z krajów UE (oraz ich współmałżonków pochodzących z krajów trzecich) mężczyźni stanowią 51,6\%, a kobiety 48,4\%. Dla cudzoziemców spoza UE jest to odpowiednio 53,7\% (mężczyźni) i 46,3\% (kobiety), zob. Secretaría de Estado de Inmigración y Emigración, b.d.. Stan na 31.12.2011 niewiele się różni od tych danych z trzeciego trymestru 2011, zob. „Extranjeros residentes en España...”, 2011. Najbardziej sfeminizowane grupy imigranckie to te pochodzące z Paragwaju i Brazylii. Najwięcej mężczyzn przyjeżdża natomiast z Senegalu i Pakistanu („Extranjeros residentes en España...”, 2011).

29 Obecnie funkcjonuje pod nazwą Secretaría General de Inmigración y Emigración.

30 Co ciekawe, edycja kolejnego rocznika z 2011 (wydanego w marcu 2012) nie odnosiła się już bezpośrednio do kryzysu (jak dwa poprzednie), ale nosiła optymistyczny tytuł "Czas integracji": "La hora de la integración, Anuario de la inmigración en España. Edición" (2011). 
5 mln obywateli (Sanmartín, 2011). Nie widać też bezpośredniej zależności między intensywnością kryzysu a wzrostem napięć społecznych i tendencji ksenofobicznych względem cudzoziemców. Rezultaty studium wskazują, że wskaźniki rasizmu i ksenofobii w społeczeństwie hiszpańskim nie zmieniły w sposób znaczny swoich wartości w porównaniu z czasem sprzed kryzysu (Aja i in., 2010) ${ }^{31}$. Hiszpanie, zdaniem autorów analizy, są bardziej otwarci i tolerancyjni względem imigrantów niż obywatele innych krajów zachodnioeuropejskich. Poza incydentalnymi przypadkami dyskryminacji nie pojawiają się w Hiszpanii poważne problemy z akceptacją "obcych”. "Kryzys nie zniszczył w znaczący sposób tego łagodnego usposobienia, z jakim hiszpańskie społeczeństwo zaakceptowało 5 mln przybyszów" - ocenia sytuację Joaquín Arango. Autorzy rocznika pokazują również, że kryzys wcale nie wpłynął na stopień bezrobocia w tak wielkim stopniu, jak się tego spodziewano. Ekonomista Josep Oliver ocenia, że w porównaniu z sytuacją autochtonów, imigrantom udało się dość dobrze obronić przed paraliżem w sektorze zatrudnienia. Dodaje, że już w 2010 roku postęp bezrobocia wśród imigrantów znacznie spowolnił. W porównaniu z okresem bezpośrednio sprzed kryzysu, w 2010 roku liczba zatrudnionych w Hiszpanii cudzoziemców wynosiła 3,2 mln (tylko o 240000 mniej miejsc pracy w porównaniu z poprzednim rokiem). Należy więc, zdaniem autorów studium, nieco ostrożniej podchodzić do danych wskazujących na wysokie bezrobocie wśród imigrantów.

Jak traktować tego typu interpretację? Statystyki jednoznacznie wskazują na ponad $30 \%$ bezrobotnych cudzoziemców i raczej trudno załagodzić ten stan rzeczy, odwołując się czy to do poziomu deprywacji względnej (autochtoni też stali się w dużym stopniu ofiarami kryzysu i także stanowią ogromny odsetek bezrobotnych), czy to do sytuacji na rynku pracy przed nadejściem kryzysu, kiedy liczba pracujących cudzoziemców wcale nie była o wiele wyższa niż w roku 2010. Warto jeszcze zauważyć, że do zespołu badaczy "demontujących" stereotypy na temat imigrantów i zapaści w obszarze zatrudnienia dołączył ówczesny minister pracy i imigracji, Valeriano Gómez. W jednym z rozdziałów rocznika napisał optymistycznie, że w obliczu kryzysu imigranci wykazali „ogromną umiejętność adaptacji do konieczności i wymagań wypływających z procesu destrukcji zatrudnienia (...)" (Sanmartín, 2011). Gdyby zapytać o to samych zainteresowanych, zapewne ich opinie nie byłyby tak jednoznacznie optymistyczne.

Jaki jeszcze wniosek wynika z cytowanego już "Rocznika Imigracji w Hiszpanii"? Hiszpania będzie nadal potrzebowała imigrantów. „Jeżeli zanikłaby imigrancka siła robocza kraj przestałby funkcjonować" - ostrzega Josep Oliver (Sanmartín, 2011)32. Tak więc, kiedy tylko hiszpański rynek pracy powróci do równowagi, powstanie ogromna luka pokoleniowa, będzie brakować młodych osób zdolnych do pracy. W związku z tym od połowy bieżącej dekady, mniej więcej od 2015 roku, kraj będzie potrzebował nowego "zastrzyku” cudzoziemskiej siły roboczej („Los expertos prevén...”, 2011).

Pod kontrowersyjnym artykułem z „El Mundo” (Sanmartín, 2011) pojawiło się także aż 39 komentarzy czytelników gazety, którzy w większości nie zgadzali się z prezentowanymi przez autora tekstu tezami. Powracał wątek zasiłków państwowych dla imigrantów, którzy aby ich nie utracić decydują się pracować nielegalnie („na czarno”). W opiniach czytelników, cudzoziemscy pracownicy zarabiają niewiele, wykonują prace, których Hi-

31 Autorzy rocznika powołują się na badania przeprowadzane regularnie przez Centrum Badań Socjologicznych (CIS) oraz Observatorio Español del Racismo y la Xenofobía (por. Observatorio Español del Racismo y de la Xenofobía, b.d.).

32 W latach 2009-2010 Hiszpania straciła 170000 aktywnych imigrantów w wieku 16-34 lat. W tym samym czasie populacja hiszpańska w tym przedziale wiekowym zmniejszyła się o 550000 wskutek spadku liczby urodzeń (Sanmartín, 2011). 
szpanie już nie chcą się podejmować i akceptują niższe pensje. I - jak można wywnioskować z komentarzy na forum - taka sytuacja właściwie by autochtonom nie przeszkadzała. Problemem jest natomiast to, że wielu cudzoziemców, pracując "na czarno", nie odprowadza podatków (co przekłada się na wyższy zarobek "na rękę"), a przy tym oficjalnie są utrzymywani z subwencji państwowych, ponieważ regularnie pobierają zasiłki. Jeden z czytelników zauważył: „(...) muszę opłacać sobie prywatne przedszkole [dla dzieci] ponieważ oni mają więcej przywilejów niż ja". Ktoś inny rozwinął ten wątek dyskusji, wyliczając, że w 2010 roku 75\% dofinansowań na przedszkole otrzymali imigranci. Dodaje, że cudzoziemcy dostają zasiłki "na wszystko", a do tego np. bezpłatne porady prawne czy księgowe, na które nie może liczyć żaden Hiszpan. Inny głos w sprawie był bardziej radykalny: „Nie pójdą stąd nawet, kiedy im za to zapłacimy. Mają dostęp do różnego rodzaju zasitków i zapomóg, których Hiszpanie nie mają. Pracując we własnym kraju, zarobiliby dużo mniej, niż dostają tutaj będąc na zasiłku”. Inni się denerwują: „(...) Czy nasi politycy nie wmawiali nam, że cała ta imigracja to cud i że wszyscy oni przyjeżdżają do nas, żeby ciężko pracować na nasze emerytury, płacić na nie składki itd.? Cholera, teraz będzie tak, że to my [Hiszpanie] będziemy musieli o wiele dłużej pracować, aby zapłacić za 'ich' emerytury". Czytelnik oskarżył kolejne rządy Hiszpanii, że próbowały przypodobać się imigrantom, nadając im coraz więcej przywilejów i praw, obojętnie czy pojawiali się tutaj legalnie, czy nielegalnie. Kolejna z czytelniczek oburzona wspomniała o Rumunach, którzy pracuja jako malarze pokojowi bez kontraktu po to, by utrzymać zasiłek: „Prawda jest taka, że chciałabym, aby ten kto przyjeżdża do pracy płacił podatki i wyjeżdżał stąd kiedy praca mu się skończy. Mam dość tej politycznej poprawności (...) kto chce niech sobie przygarnie tych pracujących na czarno do własnego domu i niech ich utrzymuje"33.

Jeszcze jeden interesujący głos w dyskusji pojawił się w artykule BBC Mundo z października 2011 („España tiene más inmigrantes a pesar de la crisis”, 2011). W tytule tekstu zawarto komunikat obalający popularne w Hiszpanii przekonanie: mimo kryzysu imigranci ciągle przyjeżdżają. Pewne grupy, jak Ekwadorczycy, opuszczają Hiszpanię, ale nadal ściągają tu inni Latynosi: Boliwijczycy i Paragwajczycy. W porównaniu z 2010 rokiem ich liczba wzrosła odpowiednio o 24 i 23\%. Boliwijczycy przyjeżdżają jednak nie tyle do pracy, ile w wyniku procedur łączenia rodzin albo na studia. Według danych Observatorio Permanente de la Inmigración, w trzecim kwartale 2011 roku liczba imigrantów wynosiła 5140 000. Mowa oczywiście o legalnie przebywających cudzoziemcach, posiadających tzw. karte pobytu (tarjeta de residencia). Mimo masowych akcji regulacyjnych prowadzonych w czasie rządów Zapatero, w czasie których nielegalni imigranci mogli zalegalizować swój pobyt bez ponoszenia kary, liczba cudzoziemców sin papeles (nieudokumentowanych, nieodnotowanych w spisie) cały czas jest duża. Szacuje się ją na 0,5-1 mln osób żyjących i pracujących nielegalnie w Hiszpanii. W tekście pojawia się kilka ciekawych spostrzeżeń dotyczących aktualnych trendów migracyjnych: część imigrantów, którzy uzyskali już hiszpańskie obywatelstwo decyduje się na wyjazd do innego kraju UE lub do Stanów Zjednoczonych, już jako formalni obywatele Hiszpanii. „Kraj iberyjski” nadal jawi się dla wielu jako „raj migracyjny”. Skąd to wynika? Hiszpańskie Ministerstwo Pracy szacuje, że co prawda bezrobocie przekracza 20\%, ale jedna na cztery osoby oficjalnie bezrobotne pracuje na czarno. Dotyczy to również imigrantów, wśród których z brakiem zatrudnienia boryka się $32 \%$, ale którzy także podejmują prace nielegalnie. Milo Robles ze Stowarzyszenia Boliwijczyków w Barcelonie zwraca uwage na paradoks: jeśli rzeczywi-

\section{-....}

33 Wszystkie komentarze znajdują się pod artykutem O. R. Sanmartín (2011). 
ście procent bezrobotnych imigrantów byłby tak wysoki, to ich oszczędności przesyłane rodzinom w kraju (las remesas) powinny maleć, tymczasem rosną.

Na koniec warto przytoczyć opinię José Gonzálesa z paragwajskiego stowarzyszenia Guaraní, który zauważa prosty fakt, często uchodzący uwadze „zachodnich" komentatorów: pojęcie kryzysu oznacza zupełnie co innego dla przybyszów z krajów mniej rozwiniętych niż obszar europejski. Bardzo często przed przyjazdem do Europy żyli oni przecież W warunkach skrajnej biedy i permanentnego zagrożenia („España tiene más inmigrantes a pesar de la crisis", 2011). Czym innym jest więc doświadczenie recesji w Hiszpanii, a czym innym w krajach latynoskich czy afrykańskich, z których przybywają imigranci. Jeśli dla Hiszpanów „kryzys” oznacza brak trzynastej pensji, odjęcie dodatkowej ulgi podatkowej, nieodnowienie garderoby w stylu nowej kolekcji sezonowej, rezygnacje z kupna dodatkowego samochodu, mniej luksusowych towarów w lodówce, czy odłożenie egzotycznych wczasów na lepsze lata - wielu imigrantów takiego pojęcia „"kryzysu” po prostu nie rozumie. Dla nich kryzys to problem z zaspokojeniem pierwszorzędnych potrzeb (nakarmienie siebie i rodziny, utrzymanie domostwa), z zagwarantowaniem dzieciom dostępu do podstawowej edukacji, z zapewnieniem odpowiedniego poziomu bezpieczeństwa, higieny etc. Dla uchodźców politycznych kryzys w ich kraju to często zagrożenie wolności i życia. Dlatego dla wielu Hiszpania to ciągle atrakcyjne miejsce, w którym próbują zbudować coś od nowa.

\section{BIBLIOGRAFIA}

Aierbe, P. M. (2007, maj 23). De la patera al cayuco: la imagen de la inmigración en los medios. Diagonal. Pobrano z https://www.diagonalperiodico.net/saberes/la-patera-alcayuco-la-imagen-la-inmigracion-medios.html

Aja, E., Arango, J., \& Oliver, J. (2010). Inmigración y crisis económica: impactos actuales y perspectivas de futuro. Anuario de la inmigración en España (edición 2010). Barcelona: CIDOB.

Aparicio Gomez, R. (2007). Las "Segundas Generaciones” de Origen Inmigrante: ¿Asimilación o Integración? Puntos de Vista: Cuadernos del Observatorio de las Migraciones y la Convivencia Intercultural de la Ciudad de Madrid, (10), 7-24.

Ariza, L. J. (2008). Inmigración y crisis económica en España: Gracias por todo, pero váyanse. Revista Migrante, (1). Pobrano 5 kwietnia 2012, z http://infomigrante.org/experiencias.shtml?apc $=z-x x-1-\& x=527$

Centro de Investigación Sociológica [CIS]. (2008). Barómetro febrero 2008. Pobrano 5 kwietnia 2012, z http://www.cis.es/cis/export/sites/default/-Archivos/Marginales/2740_2759/2754/e275400.html

Centro de Investigación Sociológica [CIS]. (2011). Barómetro mayo 2011. Pobrano 5 kwietnia 2012, z http://www.cis.es/cis/export/sites/default/-Archivos/Marginales/ 2880_2899/2888/Es2888.pdf

Centro de Investigación Sociológica [CIS]. (2012). Barómetro febrero 2012. Pobrano 5 kwietnia 2012, z http://www.cis.es/cis/opencm/ES/1_encuestas/estudios/ver. jsp?estudio $=12564$

Cepada, D. (2010, luty 4). España pierde atractivo para los inmigrantes. Cinco Días. Pobrano z http://cincodias.com/cincodias/2010/02/04/economia/1265266591_850215.html 
Dehesa, de la, G. (2009). La primera gran crisis financiera del siglo XXI. Madrid: Alianza Editorial.

El efecto de la inmigración en la sostenibilidad a medio y largo plazo del sistema de pensiones en España. (b.d.). Pobrano 5 kwietnia 2012, z http://www.seg-social.es/prdi00/ groups/public/documents/binario/100618.pdf

España perderá medio millón de habitantes en la próxima década si se mantiene la tendencia demográfica. (2011, październik 7). El País. Pobrano 5 kwietnia 2012, z http:// sociedad.elpais.com/sociedad/2011/10/07/actualidad/1317938404_850215.html

España tiene más inmigrantes a pesar de la crisis. (2011, październik 1). Pobrano 5 kwietnia, 2012, z http://www.bbc.co.uk/mundo/noticias/2011/10/110930_inmigracion_aumento_espana.shtml; http://madrepatria.blogspot.com/2011/10/espana-tiene-mas-inmigrantes-pesar-de.html

Eurostat. (2011). 6.5\% of the EU population are foreigners and $9.4 \%$ are born abroad. Eurostat. Statistics in focus, (34). Pobrano 5 kwietnia 2012, z http://epp.eurostat. ec.europa.eu/cache/ITY_OFFPUB/KS-SF-11-034/EN/KS-SF-11-034-EN.PDF

Extranjeros residentes en España. Principales resultados. (2011, grudzień 31). Pobrano 5 kwietnia, 2012, z http://extranjeros.empleo.gob.es/es/Estadisticas/operaciones/concertificado/201112/Principales_resultados_31122011.pdf

Foro para la integración social de los inmigrantes. (b.d.). Pobrano 4 kwietnia 2012, z http:// www.parainmigrantes.info/foro-para-la-integracion-social-de-los-inmigrantes-933/

Gomez-Cotta, C. (2011). La clase política, entre las mayores preocupaciones de los españoles. Pobrano z http://ethic.es/2011/06/la-clase-politica-entre-las-mayores-preocupaciones-de-los-espanoles/

González Leandri, R. (2004). Przyczyny i regionalizacja hiszpańskiej migracji zewnętrznej na przełomie XIX i XX wieku. W J. E. Zamojski (Red.), Polska-Hiszpania: migracje (ss. 81-90). Warszawa: Neriton. (Migracje i Społeczeństwo, 9).

González Martínez, E. (2004). Uwagi o badaniach nad kwestią emigracji hiszpańskiej na kontynent amerykański. W J. E. Zamojski (Red.), Polska-Hiszpania: migracje (ss. 33-40). Warszawa: Neriton. (Migracje i Społeczeństwo, 9).

Infante, A. (2011, czerwiec 23). La crisis en España empuja a los latinoamericanos e Brasil. Pobrano 5 kwietnia 2012, z http://www.bbc.co.uk/mundo/noticias/2011/06/110622_ emigracion_espana_brasil_Ir.shtml

Instituto Nacional de Estadística [INE]. (2011). Avance del Padrón municipal a 1 de enero de 2011. Pobrano 5 kwietnia 2012, z http://www.ine.es/prensa/np648.pdf

Instituto Nacional de Estadística [INE]. (2012a). Extranjeros en la UE y en España. Boletín informativo del Instituto Nacional de Estadística, (6/2012). Pobrano z www.ine.es

Instituto Nacional de Estadística [INE]. (2012b). Población de España a Corto Plazo 20112021. Pobrano 5 kwietnia 2012, z http://www.ine.es/prensa/np679.pdf

Instituto Nacional de Estadística [INE]. (b.d.). Revisión del Padrón municipal 2001. Población extranjera por sexo, país de nacionalidad y edad. Pobrano 5 kwietnia 2012, z www.ine.es

Kłoskowska, A. (1996). Kultury narodowe u korzeni. Warszawa: PWN.

La crisis dispara el rechazo a los inmigrantes. (2010, marzec 2). ABC. Pobrano 5 kwietnia 2012, z http://www.abc.es/20100302/nacional-inmigracion/crisis-dispara-rechazo-inmigrantes-201003021058.html

La hora de la integración. Anuario de la inmigración en España. Edición 2011. (2011). Pobrano 7 kwietnia 2012, z http://www.cidob.org/es/publicaciones/anuarios/anuario_de_ la_inmigracion_en_espana 
Lario Bastida, M. (2005). La imagen de la inmigración en la prensa escrita murciana. Una mirada a la evolución histórica: temas y discursos. W A. Pedreño Cánovas \& M. Hernández Pedreño, La condición inmigrante: exploración e investigaciones desde la Región de Murcia (ss. 181-196). Murcia: Universidad de Murcia.

Los expertos prevén un „nuevo choque migratorio” a partir de 2015. (2011, marzec 31). Publico.es. Pobrano 5 kwietnia 2012, z http://www.publico.es/espana/369032/los-expertos-preven-un-nuevo-choque-migratorio-a-partir-de-2015

Los extranjeros no comunitarios bajan un 6,5\% en España. (2011, styczeń 3). El País. Pobrano 5 kwietnia 2012, z http://elpais.com/elpais/2011/01/03/actualidad/ 1294046222_850215.html

Los latinoamericanos 'abandonan' España por la crisis económica y el desempleo. (2011, listopad 30). El Mundo. Pobrano 5 kwietnia 2012, z http://www.elmundo.es/ameri$\mathrm{ca} / 2011 / 11 / 30 /$ noticias/1322689703.html

Maneri, M. (2011). Media discourse on Immigration. Control Practices and the Language we Live. W S. Palidda (Red.), Racial Criminalization of Migrants in the 21 st Century (ss. 77-94). Farnham: Ashgate Publishing Limited.

Manjavacas, M. (2011, maj 9). Cuando los extranjeros deciden el nombre del alcalde de su municipio. Pobrano 5 kwietnia 2012, z http://www.cadenaser.com/espana/articulo/ extranjeros-deciden-nombre-alcalde-municipio/csrcsrpor/20110509csrcsrnac_2/Tes

Manzanedo, C., \& Gonzalez Fabre, R. (2009). Impacto de la crisis económica sobre los inmigrantes irregulares en España. Madrid: PICUM. Pobrano 5 kwietnia 2012, z http:// www.pueblosunidos.org/cpu/formacion/ImpactoCrisis.pdf

Miłkowski, T., \& Machcewicz, P. (1998). Historia Hiszpanii. Wrocław: Ossolineum.

Nalewajko, M. (2004). Obraz imigracji w prasie hiszpańskiej („El País”, październik-grudzień 2000). W J. E. Zamojski (Red.), Polska-Hiszpania: migracje (ss. 135-159). Warszawa: Neriton. (Migracje i Społeczeństwo, 9).

Observatorio Español del Racismo y de la Xenofobía. (b.d.). Pobrano 4 kwietnia 2012, z http://www.oberaxe.es

Observatorio Permanente de la Inmigración. (2011, grudzień). Pobrano 30 marca 2012, z http://extranjeros.meyss.es/es/ObservatorioPermanentelnmigracion/

Pajares, M. (2009). Inmigración y mercado de trabajo. Informe 2009. Pobrano 30 marca 2012, z http://extranjeros.meyss.es/es/ObservatorioPermanentelnmigracion/Publicaciones/archivos/Inmigracixn_y_mercado_de_trabajo._Informe_2009.pdf

Pérez de Pablos, S. (2010, maj 26). La crisis frena el número de inmigrantes que reside en España. El País. Pobrano 5 kwietnia 2012, z http://elpais.com/diario/2010/05/26/ espana/1274824817_850215.html

Portes, A., Aparicio, R., \& Haller, W. (2009). La Segunda Generación en Madrid: Un Estudio Longitudinal, Madrid. Pobrano 5 kwietnia 2012, z http://www.accionenredmadrid. org/IMG/pdf/La_Segunda_Generacion_en_Madrid.pdf

Prada De, M. A., Actis, W., \& Pereda, C. (2002). Como abordar el estudio de las migraciones? W F. Checa (Red.), Las migraciones a debate, IV Congreso de Inmigración Africana (ss. 17-54). Barcelona: Icaria.

Rainsford, S. (2011, maj 5). La crisis saca a los inmigrantes de España. Pobrano 5 kwietnia 2012, z http://www.bbc.co.uk/mundo/noticias/2011/05/110504_espana_crisis_migracion_desempleo_cch.shtml

Riesco Sanz, A. (2008). ¿Repensar la sociología de las economías étnicas? El caso de la empresarialidad inmigrante en Lavapiés. Migraciones, (24), 91-134. 
Romaniszyn, K. (1999). Światowe szlaki migracyjne: przemiany i kontynuacje. W J. E. Zamojski (Red.), Migracje 1945-1995 (ss. 135-159). Warszawa: Neriton. (Migracje i Spoteczeństwo, 3).

Romaniszyn, K. (2002). Kulturowe implikacje i determinanty migracji międzynarodowych. W B. Klimaszewski (Red.), Emigracja z Polski po 1989 roku (ss. 9-27). Kraków: Grell.

Salas, J. (2010, październik 30). La integración y la crisis reducen los embarazos. Pobrano 5 kwietnia 2012, z http://www.publico.es/espana/344159/la-integracion-y-la-crisis-reducen-los-embarazos

Sanmartín, O. R. (2009, czerwiec 9). Los ecuatorianos y marroquíes, los más perjudicados por la crisis. El Mundo. Pobrano 5 kwietnia 2012, z http://www.elmundo.es/elmundo/2009/06/09/espana/1244555640.html

Sanmartín, O. R. (2011, marzec 31). Los tópicos (caídos) sobre los inmigrantes y la crisis. El Mundo. Pobrano 5 kwietnia 2012, z http://www.elmundo.es/elmundo/2011/03/31/ espana/1301586131.html

Secretaría de Estado de Inmigración y Emigración. (b.d.). Extranjeros residentes en España. Principales resultados. Pobrano 6 kwietnia 2012, z http://extranjeros.empleo. gob.es/es/Estadisticas/operaciones/con-certificado/index.html

Sven-Reher, D., \& Requena, M. (Red.). (2009). Las múltiples caras de la inmigración en España. Madrid: Alianza Editorial.

Un 65\% de los jóvenes españoles está dispuesto a cambiar de país por un trabajo. (2012). Pobrano z http://www.randstad.es/content/aboutrandstad/noticias-eventos/noticias/ candidate/2012/Movilidad-Internacional.xml 